\title{
PENGARUH MEDIA PEMBELAJARAN DAN MOTIVASI BERPRESTASI TERHADAP HASIL BELAJAR TIK SUB JARINGAN KOMPUTER SISWA KELAS IX SMP NEGERI 1 PEGAJAHAN KABUPATEN SERDANG BEDAGAI
}

\author{
Irwan Fauzi ${ }^{1}$, Hamonangan Tambunan ${ }^{2}$ \\ Teknologi Pendidikan Pascasarjana Universitas Negeri Medan \\ Irwan_fauzi@yahoo.com ${ }^{1}$
}

\begin{abstract}
Abstrak: Tujuan penelitian ini adalah: (1) untuk mengetahui Hasil belajar TIK siswa yang diajarkan dengan media animasi 3D dengan yang diajarkan dengan media animasi 2D. (2) untuk mengetahui hasil belajar siswa yang mempunyai motivasi berprestasi tinggi dengan motivasi berprestasi rendah. (3) untuk mengetahui adanya interaksi antara media pembelajaran dan motivasi berprestasi dalam mempengaruhi hasil belajar TIK. Metode penelitian menggunakan metode quasi eksperimen dengan desain penelitian faktorial $2 \times 2$. Teknik analisis data menggunakan ANAVA pada taraf signifikan $\alpha=0,05$. Hasil penelitian menunjukkan bahwa: (1) hasil belajar TIK siswa yang diajar dengan media animasi 3D lebih tinggi daripada hasil belajar TIK siswa yang diajar dengan media animasi 2D, (2) hasil belajar TIK siswa yang mempunyai motivasi berprestasi tinggi lebih tinggi daripada hasil belajar TIK yang mempunyai motivasi berprestasi rendah, dan (3) terdapat interaksi antara media pembelajaran dan motivasi berprestasi terhadap hasil belajar TIK siswa. Hasil penelitian ini menyimpulkan bahwa media animasi 3D lebih baik diajarkan kepada siswa yang mempunyai motivasi berprestasi tinggi dan media animasi 2D baik digunakan kepada siswa yang mempunyai motivasi berprestasi rendah dan terdapat interaksi antara media pembelajaran dan motivasi berprestasi.
\end{abstract}

Kata Kunci: media animasi 3D, media animasi 2D, motivasi berprestasi, belajar TIK

\begin{abstract}
The purpose of this study are: (1) to assess the learning outcomes of ICT students taught with $3 \mathrm{D}$ animation media to those taught by the media of $2 \mathrm{D}$ animation. (2) to assess learning outcomes of students with high achievement motivation with low achievement motivation. (3) to investigate the interaction between media learning and achievement motivation in influencing ICT learning outcomes. The research method using quasi-experimental research design $2 \times 2$ factorial Data were analyzed using ANOVA at the significant level $\alpha=0.05$. The results showed that: (1) the results of ICT learning students who are taught by media 3D animation higher in the ICT learning students who are taught by the media of 2D animation, (2) the results of ICT learning students with high achievement motivation is higher than the results of ICT learning who have low achievement motivation, and (3) there is no interaction between the media learning and achievement motivation on ICT learning outcomes of students. The results of this study concluded that the media better 3D animation is taught to students with high achievement motivation and good 2D animation media used to students with low achievement motivation and there was an interaction between the media learning and achievement motivation.
\end{abstract}

Keywords: media 3D animation, $2 D$ animation media, achievement motivation, learning ICT

\section{PENDAHULUAN}

Keberhasilan belajar siswa ditentukan oleh banyak faktor pendukung, di antaranya yang terpenting adalah pemanfaatan media belajar yang baik. Menurut Nana Sudjana dalam Pupuh F. (2007: 66) bahwa dalam proses pembelajaran media dapat berfungsi sebagai: (1) alat bantu untuk mewujudkan situasi belajar mengajar yang efektif, (2) merupakan bagian yang integral dari keseluruhan situasi mengajar yang berarti salah satu unsur yang harus dikembangkan, (3) bukan semata-mata sebagai alat hiburan yang digunakan hanya untuk sekedar melengkapi proses belajar mengajar supaya lebih menarik perhatian siswa, (4) lebih diutamakan untuk mempercepat proses belajar mengajar dan membantu siswa dalam menangkap pengertian yang diberikan guru, (5) penggunaan media dalam pembelajaran 
diutamakan untuk mempertinggi mutu belajar mengajar.

Bloom (1982: 11) mengemukakan tiga faktor utama yang mempengaruhi hasil belajar, yaitu kemampuan kognitif, motivasi berprestasi dan kualitas pembelajaran. Kualitas pembelajaran adalah kualitas kegiatan pembelajaran yang dilakukan dan ini menyangkut model pembelajaran yang digunakan. Seperti dimaklumi, bahwa sudah sejak lama praktik pembelajaran di Indonesia pada umumnya cenderung dilakukan secara konvensional yaitu melalui teknik komunikasi oral. Sering ditemukan di lapangan bahwa guru menguasai materi suatu subjek dengan baik tetapi tidak dapat melaksanakan kegiatan pembelajaran dengan baik. Hal itu terjadi karena kegiatan tersebut tidak didasarkan pada model pembelajaran atau media pembelajaran tertentu sehingga hasil belajar yang diperoleh siswa rendah. Seperti yang dikatakan oleh Suparman (1993:166) bahwa metode instruksional berfungsi sebagai cara dalam menyajikan (menguraikan, memberikan contoh, dan memberi latihan) isi pelajaran kepada siswa untuk mencapai tujuan tertentu. Metode dan teknik yang dipilih oleh guru dimaksudkan agar dapat memberikan, kemudahan, fasilitas, dan atau bantuan lain kepada siswa dalam mencapai tujuan-tujuan instruksional.

Prinsip utama pemilihan media pembelajaran adalah efektivitas media pembelajaran dalam mencapai tujuan pembelajaran serta efektivitasnya dalam membantu siswa memahami materi pembelajaran yang akan disajikan. Guru harus menimbang-nimbang apakah suatu media pembelajaran yang akan digunakan lebih efektif bila dibandingkan dengan media yang lain.

Salah satu faktor pendukung dalam keberhasilan pembelajaran adalah media. SMPN 1 Pegajahan memiliki ruang laboratorium Komputer, namun kurang lengkap dan kurang mendukung untuk pembelajaran TIK. Sebenarnya hal ini bisa ditanggulangi dengan memanfaatkan kecanggihan teknologi yang ada dengan menggunakan media yang guru tampilkan di dalam kelas. Selama ini guru hanya menampilkan media power point yang konvensional sehingga peserta didik merasa jenuh dan bosan dalam pembelajaran TIK. Kejenuhan yang dirasakan peserta didik membuat peserta didik kurang maksimal. Maka untuk mengatasi hal ini, guru harus menampilkan media yang membuat peserta didik merespon, bahkan terpesona dengan pembelajaran TIK.

Teknologi Informasi dan Komunikasi (TIK) adalah sebuah teknologi yang dipergunakan untuk mengelola data, termasuk memproses, mendapatkan, menyusun, menyimpan, memanipulasi data dengan berbagai macam cara dan prosedur guna menghasilkan informasi yang berkualitas dan bernilai guna tinggi, sementara Teknologi Komunikasi (TK) adalah teknologi yang dipergunakan untuk mentransfer aneka informasi sehingga tepat guna, tepat sasaran, dan memiliki nilai. Meski dalam praktiknya, antara TI dan TK terkadang tidak dapat dipisahkan antara satu sama lain. Hal ini disebutkan Lestari (2011) bahwa TIK adalah suatu padanan yang tidak terpisahkan yang mengandung pengertian luas tentang segala kegiatan yang terkait dengan pemrosesan, manipulasi, pengelolaan, dan transfer informasi antar media.

Secara umum TIK adalah semua aspek yang melibatkan teknologi, rekayasa, dan teknik pengelolaan yang digunakan dalam pengendalian dan pemrosesan informasi serta penggunaannya. Ada tiga komponen utama pembelajaran yang berbasis TIK yakni komputer, multimedia, dan telekomunikasi. Penggunaan TIK merupakan suatu model pembelajaran yang mendukung terwujudnya visi pendidikan global, Asyhar : 2011 (inayunanta.blogspot.com ).

Seperti yang ditulis Hendra Surya (2009: 2), ada tiga komponen yang harus dimiliki siswa agar dapat melakukan kegiatan (proses) belajar, yaitu: (1) minat, yaitu sebagai keinginan yang kuat untuk memenuhi kepuasan berupa keinginan untuk memiliki atau melakukan sesuatu, (2) perhatian adalah proses pemusatan pengerahan aktivitas tenaga psikis dan fisik terutama indra dan gerakan tubuh pada fokus tertentu, dan (3) motivasi adalah dorongan atau usaha untuk mewujudkan perbuatan dalam aktivitas mencapai kebutuhan atau tujuan tertentu. Ketiga komponen ini saling berkait untuk mendapatkan hasil belajar yang maksimal.

Animasi yang akan digunakan dalam penelitian ini yaitu animasi 2D menggunakan macromedia flas $\mathrm{mx}$ dan animasi 3D 
menggunakan max 2012. Animasi 3D sendiri adalah sebuah model yang mempunyai bentuk, volume, dan ruang sehingga dapat dilihat dari segala arah. Animasi 3D adalah pengembangan dari animasi 2D. Dengan animasi 3D, karakter yang diperlihatkan semakin hidup dan nyata, mendekati wujud manusia aslinya (http://ginafebriani.wordpress.com). Perbedaan animasi 2D dan 3D adalah dilihat dari sudut pandangnya. Animasi 2D menggunakan koordinat $\mathrm{x}$ dan $\mathrm{y}$, sedangkan animasi 3D menggunakan koordinat $\mathrm{x}, \mathrm{y}$, dan $\mathrm{z}$ yang memungkinkan kita dapat melihat sudut pandang objek secara lebih nyata.

Prestasi belajar siswa selalu berkaitan dengan motivasi berprestasi karena motivasi merupakan penggerak dan pendorong manusia bertindak dan berbuat sesuatu. Menurut beberapa studi kepribadian, salah satu karakteristik yang menentukan kesuksesan siswa adalah tingginya kebutuhan untuk berprestasi (Cox,1995: 44). Kebutuhan inilah yang dikenal sebagai achievement motivation. Orientasi teori ini dilandasi oleh sukses berdasarkan persepsi siswa.

Menurut Heckhausen (1967: 58) motif berprestasi selalu mengandung dua hal yang bertentangan, yaitu "harapan untuk sukses" dan "ketakutan akan gagal". Bila harapan untuk sukses kuat sedangkan ketakutan akan gagal lemah, maka siswa akan merasa mantap tidak mengalami stress atau gangguan-gangguan psikologis, sebaliknya bila ketakutan akan gagal lebih kuat daripada harapan untuk sukses, maka siswa akan mengalami stress dan rasa percaya diri akan dapat goyah.

Sebelum membahas hasil belajar jenisjenis jaringan komputer, perlu dijelaskan hakikat belajar dan hasil belajar itu sendiri. Belajar adalah suatu proses yang kompleks yang terjadi pada semua orang dan berlangsung seumur hidup, sejak ia masih bayi sampai ke liang lahat nanti (Sadiman, dkk. 2003:2).

Menurut teori belajar behaviorisme (Hamid K, 2009 :8), belajar adalah perubahan tingkah laku yang terjadi berdasarkan paradigma stimulus-respon (S-R), yaitu suatu proses memberikan respon tertentu kepada stimulus yang datang dari luar. Sedangkan menurut teori belajar kognitivisme belajar bukan hanya pembentukan tingkah laku yang diperoleh karena pengulangan hubungan S-R dan adanya reward dan reinforcement tetapi merupakan fungsi pengalaman-pengalaman perceptual dan proses kognitif yang mencakup ingatan, retensi, lupa, pengelolahan, informasi, dan sebagainya. Teori belajar menurut konstruktivisme, yang merupakan salah satu filsafat pengetahuan, menekankan bahwa pengetahuan kita itu adalah konstruksi (bentukan) kita sendiri. Menurut pandangan teori konstruktivisme, belajar merupakan proses aktif dari subjek belajar untuk merekonstruksi makna sesuatu, entah itu teks, kegiatan dialog, pengalaman fisik dan lain-lain, sehingga belajar merupakan proses mengasimilasikan dan menghubungkan pengalaman atau bahan yang dipelajarinya dengan pengertian yang sudah dimiliki, dengan demikian pengertiannya menjadi berkembang. Jadi menurut teori konstruktivisme, belajar adalah kegiatan yang aktif di mana siswa membangun sendiri pengetahuannnya dan mencari sendiri makna dari sesuatu yang mereka pelajari.

Skinner dalam Hergenhahn dan Olson (2012:4) menyatakan perubahan perilaku merupakan proses belajar itu sendiri dan tak perlu lagi ada proses lain yang harus disimpulkan. Perubahan-perubahan yang terjadi tidak karena perubahan fisik atau kedewasaan, tidak karena kelelahan, penyakit atau pengaruh obat-obatan, melainkan terjadi sebagai akibat interaksinya dengan lingkungannya. Perubahan tersebut haruslah bersifat relative permanen dan menetap, tidak berlangsung sesaat saja (Winkel, 1996:53). Sardiman (2005:21) bahwa "perubahan tidak hanya berkaitan dengan penambahan ilmu pengetahuan, tetapi juga berbentuk kecakapan, keterampilan, sikap, pengertian, harga diri, minat, watak dan penyesuaian diri"..

Kegiatan belajar merupakan kegiatan yang paling penting dalam proses pendidikan di sekolah, ini berarti bahwa tidaknya pencapaian tujuan pendidikan banyak tergantung pada bagaimana proses belajar yang dialami murid sebagai anak didik, maka kegiatan belajar itu cenderung diketahui sebagai suatu proses psikologi, terjadi di dalam diri seseorang. Oleh karena itu sulit diketahui dengan pasti bagaimana terjadinya. Proses yang begitu kompleks, maka timbul beberapa teori belajar. Dalam hal ini Sardiman, (2011:30) antara lain : teori jiwa daya, ilmu jiwa gestalt, ilmu jiwa asosiasi dan kontruktivisme. 
William Burton dalam Hamalik (2004:2) menyatakan bahwa: Experiencing means livings, through actual situations and recting vigorously to various aspect of those situation for purposes apparent to the learner. Experiencing includes vhatever one does or undergoes which result in changes behavior, in changed values, meaning attitudes, or skill. Pengalaman adalah sebagai sumber pengetahuan dan keterampilan, bersifat pendidikan, yang merupakan satu kesatuan disekitar tujuan murid, pengalaman pendidikan bersifat kotinue dan interaktif, membantu integrasi pribadi murid pada garis besarnya pengalaman itu terbagi menjadi dua yaitu pengalaman langsung partisipan sesungguhnya, berbuat dan sebagainya serta pengalaman pengganti yaitu melalui observasi langsung melalui gambar, grafis, kata-kata dan melalui simbol.

Menurut Sanjaya (2010 : 13), hasil belajar berkaitan dengan pencapaian dalam memperoleh kemampuan sesuai dengan tujuan khusus yang direncanakan. Perubahan tingkah laku yang diperoleh melalui hasil belajar dapat dilihat pada beberapa ciri-ciri, yaitu (1) terbentuknya tingkah laku yang berupa kemampuan aktual dan potensial, (2) kemampuan ini berlaku dalam waktu yang relatif lama, dan (3) kemampuan baru ini diperoleh melalui usaha.Sementara Hamalik (2004:30) mengatakan hasil belajar akan tampak pada setiap perubahan pada aspekaspek tersebut. Adapun aspek-aspek itu adalah: (a) pengetahuan, (b) pengertian, (c) kebiasaan, (d) keterampilan, (e) apresiasi, (f) emosional, (h) hubungan sosoial, (i) jasmani, (j) etis atau budi pekerti, dan (k) sikap..

Pendapat lain tentang hasil belajar dikemukakan oleh Briggs (dalam Taruh, 2003: 17) yang mengatakan bahwa hasil belajar adalah seluruh kecakapan dan hasil yang dicapai melalui proses belajar mengajar di sekolah yang dinyatakan dengan angka-angka atau nilai-nilai berdasarkan tes hasil belajar. Hal ini senada dengan Rasyid (2008: 9) yang berpendapat bahwa jika ditinjau dari segi proses pengukurannya, kemampuan seseorang dapat dinyatakan dengan angka. Dengan demikian, hasil belajar siswa dapat diperoleh guru dengan terlebih dahulu memberikan seperangkat tes kepada siswa untuk menjawabnya. Hasil tes belajar siswa tersebut akan memberikan gambaran informasi tentang kemampuan dan penguasaan kompetensi siswa pada suatu materi pelajaran yang kemudian dikonversi dalam bentuk angka-angka. Bloom dan Kratwohl (dalam Usman, 1994: 29) bahwa hasil belajar merupakan perubahan tingkah laku yang secara umum dapat dikelompokkan ke dalam tiga kategori yaitu ranah kognitif, afektif, dan psikomotor.

Untuk mengetahui apakah seseorang telah memperoleh perubahan sebagai hasil dari belajar, maka perlu dilakukan evaluasi yang berguna sebagai alat kontrol dalam pencapaian hasil belajar. Tes atau bentuk evaluasi yang diberikan secara periodik. Tes adalah seperangkat rangsangan yang diberikan kepada seseorang dengan maksud untuk mendapatkan jawaban yang dijadikan dasar bagi penetapan skor atau angka (Arikunto, 2009 : 52).

Menurut Syaiful Bahri (2006), secara harfiah kata media memiliki arti "perantara" atau "pengantar".Sedangkan dalam Kamus Lengkap Bahasa Indonesia karangan Fahri, media adalah alat (sarana) komunikasi.Menurut Asosiasi Teknologi dan Komunikasi Pendidikan (Association of Education and CommunicationTechnology/AECT) di Amerika membatasi media sebagai segala bentuk dan saluran yang digunakan orang untuk menyalurkan pesan atau informasi. Dan agak berbeda batasan yang diberikan oleh NEA (National Education Association) berpendapat bahwa media adalah segala benda yang dimanipulasikan, dilihat, didengar, dibaca atau dibicarakan beserta instrumen yang digunakan untuk kegiatan belajar mengajar, Asnawir (2002).

Menurut Raharjo (Sukarno : 2009), definisi "media adalah: a). Media merupakan wadah atau tempat dari pesan yang oleh sumbernya akan diteruskan kepada sasarannya pesan tersebut, b). Materi yang ingin disampaikan adalah pesan pengajaran, dan tujuan yang ingin disampaikan adalah terjadinya proses belajar". Sementara itu Purnamawati dan Eldarni (Wijaya Kusumah : 2008), mengemukakan "Media adalah segala sesuatu yang dapat digunakan untuk menyalurkan pesan dari pengirim ke penerima sehingga dapat merangsang pikiran, perasaan, perhatian dan minat siswa sedemikian rupa sehingga terjadi proses belajar". Pada artikel yang sama Heinich, Molenda, Russel 
menyatakan bahwa media adalah: "A medium (plural media) is a channel of communication, example include film, television, diagram, printed materials, computers, and instructors. (Media adalah saluran komunikasi termasuk film, televisi, diagram, materi tercetak, komputer, dan instruktur"). Sedangkan menurut Oemar Hamalik dalam bukunya Fatah Syukur (2005), mendefinisikan "Media sebagai teknik yang digunakan dalam rangka lebih mengefektifkan komunikasi antara guru dan murid dalam proses pendidikan dan pengajaran di sekolah".

Kata media merupakan bentuk jamak dari kata medium yang berarti perantara atau pengantar terjadinya komunikasi dari pengirim menuju penerima. Media adalah berbagai jenis komponen dalam lingkungan siswa yang dapat merangsang untuk belajar. (Gagne dalam Daryanto, $2010: 157$ )

Pengertian Animasi Menurut Ibiz Fernandes dalam bukunya Macromedia Flash Animation \& Cartooning: A creative Guide (http://ginafebriani.wordpress.com/), animasi definisikan sebagai berikut: "Animation is the process of recording and playing back a sequence of stills to achieve the illusion of continues motion" ( Ibiz Fernandez McGrawHill/Osborn, California, 2002)

Penjelasan animasi didasarkan pada basis dimensi yang diterapkan. Terdapat dua jenis animasi yakni animasi dua dimensi $(2 D$ animation) dan animasi tiga diamensi ( $3 D$ animation). Animasi dua dimensi hanya menggunakan dua aksis (sudut pandang) yakni $\mathrm{X}$ mewakili lebar dan gerakan kiri-kanan, dan y mewakili tinggi dan gerakan atas bawah. Gambar pada animasi dua dimensi bisa dianalogikan dengan wayang kulit. Tak ada ketebalan pada animasi dua dimensi. Animasi 3D sendiri adalah sebuah model yang mempunyai bentuk, volume, dan ruang sehingga dapat dilihat dari segala arah. Animasi tiga dimensi menggunakan tiga aksis (sudut pandang), yakni $\mathrm{x}, \mathrm{y}$, dan Z.Aksis $\mathrm{Z}$ mewakili ketebalan dan gerakan maju mundur. Dengan tiga aksis maka objek dan gerakan lebih realistis. Bentuk objek memiliki lebar, tinggi, dan ketebalan. Gerakan objek bisa ke samping, atas-bawah, dan maju-mundur. Pada animasi tiga dimensi juga dapat dikreasi efek-efek relistis seperti pencahayaan dan bayangan.
Sardiman (2011 : 73) menyebutkan bahwa motivasi berpangkal dari kata "motif"yang dapat diartikan daya penggerak yang ada di dalam diri seseorang untuk melakukan aktivitas-aktivitas tertentu demi tercapainya suatu tujuan. Motivasi diartikan juga sebagai suatu kekuatan sumber daya yang menggerakkan dan mengendalikan perilaku manusia. Motivasi merupakan sebuah upaya yang dapat memberikan dorongan kepada seseorang untuk mengambil suatu tindakan yang dikehendaki. Dalam kegiatan belajar, motivasi dapat dikatakan sebagai keseluruhan daya penggerak di dalam diri siswa yang menimbulkan, menjamin kelangsungan dan memberikan arah kegiatan belajar, sehingga diharapkan tujuan dapat tercapai. Ada tiga elemen atau ciri pokok dalam motivasi itu, yakni motivasi itu mengawali terjadinya perubahan energi, ditandai dengan adanya feeling dan dirangsang karena adanya tujuan.

Berprestasi adalah idaman setiap individu, baik itu prestasi dalam bidang pekerjaan, pendidikan, sosial, seni, politik, budaya dan lain-lain. Dengan adanya prestasi yang pernah diraih oleh seseorang akan menumbuhkan suatu semangat baru untuk menjalani aktifitas. Pengertian prestasi menurut Murray (dalam J. Winardi, 2004): "...Melaksanakan tugas atau pekerjaan yang sulit. Menguasai, memanipulasi atau mengorganisasi objek-objek fiskal, manusia atau ide-ide untuk melaksanakan hal-hal tersebut secepat mungkin dan seindependen mungkin sesuai kondisi yang berlaku. Mencapai performan puncak untuk diri sendiri. Mampu menang dalam persaingan dengan pihak lain. Meningkatkan kemampuan diri melalui penerapan bakat secara berhasil."

Pengertian kebutuhan untuk berprestasi menurut McClelland (dalam Alex Sabur, 2003:285) adalah suatu daya dalam mental manusia untuk melakukan suatu kegiatan yang lebih baik, lebih cepat, lebih efektif, dan lebih efisien daripada kegiatan yang dilaksanakan sebelumnya. Ini disebabkan oleh virus mental. Dari pendapat tersebut Alex Sabur mengartikan bahwa dalam psikis manusia, ada daya yang mampu mendorongnya ke arah suatu kegiatan yang hebat sehingga dengan daya tersebut, ia dapat mencapai kemajuan yang teramat cepat. Daya pendorong tersebut dinamakan virus mental, karena apabila berjangkit di dalam jiwa 
manusia, daya tersebut akan berkembang biak dengan cepat. Dengan kata lain, daya tersebut akan meluas dan menimbulkan dampak dalam kehidupan. Ahli lain yakni Gellerman (1963: 67) menyatakan bahwa orang yang mempunyai motivasi berprestasi tinggi akan sangat senang kalau ia berhasil memenangkan suatu persaingan. Ia berani menanggung segala resiko sebagai konsekuensi dari usahanya untuk mencapai tujuan. Sedangkan motivasi berprestasi menurut Tapiardi (1996:105) adalah sebagai suatu cara berfikir tertentu apabila terjadi pada diri seseorang cenderung membuat orang itu bertingkah laku secara giat untuk meraih suatu hasil atau prestasi.

Komarudin (1994) menyebutkan bahwa motivasi berprestasi meliputi pertama kecenderungan atau upaya untuk berhasil atau mencapai tujuan yang dikehendaki; kedua keterlibatan ego individu dalam suatu tugas; ketiga harapan suatu tugas yang terlihat oleh tanggapnya subyek; keempat motivasi untuk mengatasi rintangan atau berupaya berbuat sesuatu dengan cepat dan baik. (http://patriotproklamasi.blogspot.com/2006/03 /motivasi-berprestasi-html, diakses tanggal 10 September 2010). Menurut ahli lain, J.P Chaplin dalam Hendra Surya (2009: 52), motivasi berprestasi diartikan sebagai: 1) kecenderungan untuk mencapai sukses atau memperoleh apa yang menjadi tujuan akhir yang dikehendaki, 2) keterlibatan diri seseorang terhadap suatu tugas, 3) harapan untuk berhasil dalam suatu tugas yang diberikan, dan 4) dorongan untuk mengatasi rintangan-rintangan atau perjuangan melakukan pekerjaanpekerjaan yang sulit secara cepat dan tepat. Dengan kata lain, motivasi berprestasi merupakan salah satu ciri karakter dari kepribadian kuat seseorang. Orang yang memiliki motivasi berprestasi adalah orang yang tahu bagaimana menyusun jalan pikiran dan usaha langkah demi langkah yang terarah serta kerja keras untuk mencapai prestasi itu sendiri.

Motivasi berprestasi mengandung dua aspek, yaitu (1) mencirikan ketahanan dan suatu ketakutan akan kegagalan dan (2) meningkatkan usaha keras yang berguna dan mengharapkan akan keberhasilan (McClelland, 1976: 74-75). Perilaku kerja prestatif - Motif Berprestasi Tinggi dapat dimulai dari lingkungan keluarga, lingkungan sekolah maupun dari lingkungan masyarakt hal itu merupakan salah satu kemampuan manusia yang dapat memberi kepuasan dan keberhasilan dalam hidup sehingga manusia dapat mengktualisasikan dirinya ke dalam lingkungan dimana dia berada. Namun, Travers (1982:435) mengatakan bahwa ada dua kategori penting dalam motivasi berprestasi, yaitu mengharapkan akan sukses dan takut akan kegagalan. Uraian di atas menunjukkan bahwa setidak-tidaknya ada dua indikator dalam motivasi berprestasi (tinggi), yaitu kemampuan dan usaha. Namun, bila dibandingkan dengan atribusi intrinsik dari Wainer, ada tiga indikator motivasi berprestasi tinggi yaitu: kemampuan, usaha, dan suasana hati (kesehatan). Berdasarkan uraian di atas, hakikat motivasi berprestasi dalam penelitian ini adalah rangsangan-rangsangan atau daya dorong yang ada dalam diri yang mendasari kita untuk belajar dan berupaya mencapai prestasi belajar yang diharapkan.

Hasil penelitian Fernald seperti yang dilaporkan oleh Lili Garliah dan Fatma Kartika Sary Nasution (2005: 39) menyebutkan beberapa hal yang dapat mempengaruhi motivasi seseorang yaitu: 1) keluarga dan kebudayaan (family and cultural), yaitu motivasi dapat dipengaruhi oleh lingkungan sosial dan teman, pola asuh orang tua juga memberikan pengaruh terhadap motivasi berprestasi anak, 2) konsep diri (self concept), konsep diri merupakan bagaimana seseorang berfikir mengenai dirinya sendiri. Apabila dirinya percaya mampu melakukan sesuatum maka individu tersebut akan termotivasi untuk melakukan hal tersebut sehingga berpengaruh dalam bertingkah laku, 3) jenis kelamin (sex roles) prestasi yang tinggi biasanya diidentikkan dengan maskulinitas, sehingga banyak para wanita belajar tidak maksimal khususnya wanita tersebut berada diantara para pria.

Motivasi berprestasi atau kebutuhan untuk berprestasi (needs for achievement), pertama kali diperkenalkan oleh David McClelland. Menurut McClelland untuk membuat sebuah pekerjaan berhasil, maka yang terpenting adalah sikap terhadap pekerjaan tersebut. Dia melakukan penelitian yang sangat dalam mengenai motif dalam hubungan dengan kebutuhan untuk berprestasi. Hasil penelitiannya menunjukkan bahwa jatuh 
bangunnya negara-negara beserta kebudayaannya berhubungan erat dengan perubahan pada kebutuhan untuk beprestasi warganya (Alex Sobur, 2003:284).

McClelland juga menemukan bahwa siswa dengan motivasi berprestasi rendah mempunyai kecenderungan berpikir lebih banyak tentang ketidakpastian, rintangan, hambatan, dan kemungkinan mendapatkan peristiwa yang tidak terduga (kebetulan) ketika dibangkitkan asosiasinya tentang keberhasilan daripada siswa dengan motivasi berprestasi tinggi (McClelland, 1976:252).

Menurut McClelland dalam Fasti Rola (2006:8) bahwa individu yang memilki motivasi berprestasi tinggi individu yang memiliki standar berprestasi, memiliki tanggungjawab pribadi atas kegiatan yang dilakukannya, individu lebih suka bekerja pada siatuasi dimana dirinya mendaptkan umpan balik sehingga dapat diketahui seberapa baik tugas yang telh dilakukannya, individu tidak menyukai keberhasilan yang bersifat kebetulan atau karena tindakan orang lain, individu lebih suka bekerja pada tugas yang tingkat kesulitannya menengah dan realistis dalam pencapaian tujuannya, individu bersifat inovatif dimana dalam melakukan suatu tugas dilakukan dengan cara yang berbeda, efisien, dan lebih baik daripada sebelumnya, serta individu akan merasa puas serta menerima kegagalan atau tugas-tugas yang telah dilakukannya.

McClelland dan Liberman (1949) menemukan bahwa kelompok siswa dengan motivasi berprestasi sedang (atribute), berpikir tentang jaminan atau keamanan dan terutama mengenai cara menghindari kegagalan, atau dengan keinginan minimal untuk mencapai keberhasilan. Di lain pihak, kelompok dengan motivasi berprestasi tinggi lebih berpikir tentang mencapai keberhasilan, atau dengan keinginan kuat untuk mencapai keberhasilan (McClelland, 1976:260). Perlu dicatat bahwa kebutuhan untuk berprestasi tidak selalu berkaitan dengan keberhasilan untuk mencapai tujuan. Sebagai contoh, sebagian orang yang memiliki kebutuhan berprestasi yang tinggi memberi perhatian yang besar akan keberhasilan dan bekerja keras untuk memperolehnya, tetapi untuk sebagian orang tidak selalu seperti itu. Kesimpulannya, kebutuhan seseorang untuk mencapai prestasi merefleksikan kerja keras yang dilakukannya untuk mencapai tujuan yang telah ia tetapkan (Cohen Louis, 1977: 10).

Hurlock (1996), "menyatakan bahwa dalam kehidupan sosial, remaja banyak sekali dipengaruhi oleh teman sebaya. Biasanya para remaja menghabiskan waktu dua kali lebih banyak dengan teman sebayanya daripada dengan orangtuanya." Dalam hal tersebut remaja seringkali menjadi termotivasi oleh faktor lingkungan, terutama oleh temannya. Kehidupan remaja sering terjadi prestasi antara remaja satu dengan yang lain berbeda bisa mengungguli atau sebaliknya, maka diharapkan remaja harus pandai-pandai memilih teman dalam bergaul sehingga pengaruh positif bisa didapat dari teman sebaya.

Motivasi berprestasi sangat dipengaruhi oleh peran orangtua dan keluarga. Hasil-hasil kebudayaan seperti hikayat-hikayat yang berisi pesan tentang tema-tema prestasi yang diberikan kepada seorang anak bisa mendorong untuk meningkatkan prestasinya. Konsep diri yang ada pada diri individu juga memegang peranan penting dalam menimbulkan motivasi berprestasi, karena apabila individu juga memegang peranan penting dalam menimbulkan motivasi berprestasi, karena apabila individu percaya dirinya mampu untuk melakukan sesuatu, maka akan timbul motivasi dalam diri individu untuk melakukan hal tersebut (Fasti Rola, 2006:7).

Rumusan masalah penelitian ini adalah: (1) Apakah hasil belajar TIK siswa kelas IX SMP Negeri 1 Pegajahan yang diajarkan dengan media pembelajaran animasi 3D lebih tinggi daripada hasil belajar TIK yang diajarkan dengan media pembelajaran animasi 2D?; (2) Apakah hasil belajar TIK siswa kelas IX SMP Negeri 1 Pegajahan yang memiliki motivasi berprestasi tinggi lebih tinggi daripada hasil belajar TIK siswa dengan kemampuan motivasi berprestasi rendah?; dan (3) Apakah terdapat interaksi antara media pembelajaran dan motivasi berprestasi siswa dalam mempengaruhi hasil belajar TIK siswa kelas IX SMP Negeri 1 Pegajahan?

\section{METODE}

Populasi dalam penelitian ini adalah seluruh siswa kelas IX SMP Negeri 1 Pegajahan, terdiri dari dari 6 kelas yaitu, jumlah 199 orang, Setiap kelas dalam populasi memiliki karakteristik yang sama, artinya setiap 
kelas tidak memiliki siswa yang pernah tinggal kelas, siswa rata-rata memiliki umur yang tidak jauh berbeda secara signifikan, menggunakan kurikulum pendidikan mata pelajaran TIK yang sama. Sampel penelitian dipilih secara acak dengan mengundi 6 kelas di SMP Negeri 1 Pegajahan untuk mendapat 2 kelas sebagai sampel penelitian. Dari hasil pengundiannya, terpilih dua kelas yang diajar dengan media animasi 3D yaitu kelas IX-1 dan IX-2 berjumlah 68 siswa sedangkan untuk kelas yang diajar dengan media animasi 2D diundi dari 4 kelas yang tidak terpilih, maka terpilihlah kelas IX-3 dan IX-6 berjumlah 64 siswa. Sebelum diberikan perlakuan, terlebih dahulu diberikan angket motivasi berprestasi, untuk membedakan siswa yang memiliki motivasi berprestasi tinggi dan siswa yang memiliki motivasi berprestasi rendah. Penelitian ini menggunakan metode quasi eksperimen (eksperimen semu) dengan desain faktorial $2 \times 2$. Melalui desain ini dibandingkan pengaruh perlakuan pembelajaran dengan menggunakan media pembelajaran animasi 3D dan media pembelajaran animasi 2D ditinjau dari motivasi berprestasi.

Penelitian ini menggunakan metode quasi eksperimen (eksperimen semu) dengan desain faktorial $2 \times 2$. Melalui desain ini dibandingkan pengaruh perlakuan pembelajaran dengan menggunakan media pembelajaran animasi 3D dan media pembelajaran animasi 2D ditinjau dari motivasi berprestasi.

Tabel 1. Rancangan Eksperimen Desain Faktorial 2 x 2

\begin{tabular}{|l|c|c|}
\hline \multirow{2}{*}{$\begin{array}{c}\text { Motivasi berprestasi } \\
(\mathrm{B})\end{array}$} & \multicolumn{2}{|c|}{ Media pembelajaran $(\mathrm{A})$} \\
\cline { 2 - 3 } & Animasi 3D $\left(\mathrm{A}_{1}\right)$ & Animasi $2 \mathrm{D}\left(\mathrm{A}_{2}\right)$ \\
\hline Tinggi $\left(\mathrm{B}_{1}\right)$ & $\mathrm{A}_{1} \mathrm{~B}_{1}$ & $\mathrm{~A}_{2} \mathrm{~B}_{1}$ \\
\hline Rendah $\left(\mathrm{B}_{2}\right)$ & $\mathrm{A}_{1} \mathrm{~B}_{2}$ & $\mathrm{~A}_{2} \mathrm{~B}_{2}$ \\
\hline
\end{tabular}

Keterangan :

A : Media pembelajaran

B : Memiliki motivasi berprestasi

$\mathrm{A}_{1} \quad$ : Media animasi 3D

$\mathrm{A}_{2} \quad$ : Media animasi 2D

$\mathrm{B}_{1} \quad$ : Memiliki motivasi berprestasi tinggi

$\mathrm{B}_{2} \quad$ : Memiliki motivasi berprestasi rendah

$\mathrm{A}_{1} \mathrm{~B}_{1}$ : Hasil belajar TIK siswa yang diajar dengan media pembelajaran animasi 3D pada siswa dengan motivasi berprestasi tinggi

$\mathrm{A}_{1} \mathrm{~B}_{2}$ : Hasil belajar TIK siswa yang diajar dengan media pembelajaran animasi 3D pada siswa dengan motivasi berprestasi rendah

$\mathrm{A}_{2} \mathrm{~B}_{1} \quad$ :Hasil belajar TIK siswa yang diajar dengan media pembelajaran animasi 2D pada siswa dengan motivasi berprestasi tinggi

$\mathrm{A}_{2} \mathrm{~B}_{2}$ : Hasil belajar TIK siswa yang diajar dengan media pembelajaran animasi 2D pada siswa dengan motivasi berprestasi rendah

Teknik analisis inferensial digunakan untuk menguji hipotesis penelitian dengan menggunakan teknik analisis varians (ANAVA) dua jalur. Sudjana (2002) menjelaskan sebelum ANAVA dua jalur dilakukan, terlebih dahulu ditentukan persyaratan analisis yakni persyaratan normalitas menggunakan uji Liliefors, sedangkan untuk uji persyaratan homogenitas menggunakan uji Barlet. Setelah melakukan pengujian persyaratan analisis, selanjutnya dilakukan pengujian ANAVA dua jalur, jika ternyata hasil hipotesis penelitian menyatakan ada interaksi selanjutnya dilakukan uji lanjut dengan menggunakan uji Scheffe.

Adapun hipotesis statistik yang akan diuji adalah:

1. $\mathrm{H}_{\mathrm{o}}: \mu \mathrm{A}_{1,2} \leq \mu \mathrm{A}_{3,4}$

$\mathrm{H}_{\mathrm{a}}:: \mu \mathrm{A}_{1,2}>\mu \mathrm{A}_{3,4}$

2. $\mathrm{H}_{\mathrm{o}}: \mu \mathrm{A}_{1,3} \leq \mu \mathrm{A}_{2,4}$

$\mathrm{H}_{\mathrm{a}}:: \mu \mathrm{A}_{1,3}>\mu \mathrm{A}_{2,4}$

3. $\mathrm{H}_{\mathrm{o}}$ : Interaksi $(\mathrm{B} \times \mathrm{T})=0$

$\mathrm{H}_{\mathrm{a}}$ : Interaksi $(\mathrm{B} \times \mathrm{T}) \neq 0$

\section{HASIL DAN PEMBAHASAN \\ Hasil}

Pengujian hipotesis penelitian pertama, kedua, dan ketiga dengan menggunakan teknik analisis anava faktorial $2 \times 2$ dan uji lanjut Scheffe diperlukan harga rata-rata tiap kelompok, setelah data diolah dengan anava 2 jalur maka diperoleh hasil analisis seperti pada tabel 2 
Tabel 2. Ringkasan Hasil Perhitungan ANAVA Faktorial 2 x 2

\begin{tabular}{|l|c|c|c|c|c|c|}
\hline \multicolumn{1}{|c|}{ Sumber Varians } & dk & JK & RJK & Fhitung & F Tabel 0,05 & Ket \\
\hline Media Animasi (A) & 1 & 52,28 & 52,28 & 3,57 & 3,16 & Signifikan \\
\hline Motivasi Berprestasi (B) & 1 & 44,75 & 44,75 & 3,26 & 3,16 & Signifikan \\
\hline Interaksi (AB) & 1 & 55,33 & 55,33 & 3,77 & 3,16 & Signifikan \\
\hline Galat & 128 & 2066,33 & 14,65 & & & \\
\hline Total & 131 & 2218,69 & & & & \\
\cline { 1 - 3 }
\end{tabular}

Pengujian hipotesis pertama: Hasil Belajar Tik Siswa Kelas IX SMP NEGERI 1 Pegajahan Yang Diajarkan Dengan Media Animasi 3D Lebih Tinggi Daripada Hasil Belajar Tik Yang Diajarkan Dengan Media Animasi 2D

hasil belajar TIK siswa yang diajar dengan strategi model pembelajaran jigsaw lebih tinggi dari pada hasil belajar kewirausahaan siswa yang diajar dengan strategi strategi model STAD. Hipotesis statistiknya adalah:

$\mathrm{H}_{\mathrm{o}}: \mu \mathrm{A}_{1,2} \leq \mu \mathrm{A}_{3,4}$

$\mathrm{H}_{\mathrm{a}}:: \mu \mathrm{A}_{1,2}>\mu \mathrm{A}_{3,4}$

Dari hasil perhitungan dengan ANAVA tersebut didapat bahwa harga $\mathrm{F}_{\text {hitung }}$ sebesar 3,57 dan harga $F_{\text {Tabel }}=3,16$. Karena $\mathrm{F}_{\text {hitung }}>F_{\text {Tabel }}$ maka Ho ditolak dan hipotesis alternatif diterima. Dengan demikian hipotesis penelitian yang menyatakan hasil belajar TIK antara siswa yang dibelajarkan dengan menggunakan media animasi 3D lebih tinggi dibandingkan dengan menggunakan media animasi 2D, pada taraf kepercayaan $\alpha=0,05$ telah teruji kebenarannya

Pengujian hipotesis kedua Pengujian hipotesis kedua yaitu Hasil Belajar TIK Siswa Kelas IX SMP NEGERI 1 Pegajahan Yang Memiliki Motivasi Berprestasi Tinggi Lebih Tinggi Daripada Hasil Belajar TIK Siswa Dengan Kemampuan Motivasi Berprestasi Rendah. Hipotesis statistiknya adalah:

$\mathrm{H}_{\mathrm{o}}: \mu \mathrm{A}_{1,3} \leq \mu \mathrm{A}_{2,4}$

$\mathrm{H}_{\mathrm{a}}:: \mu \mathrm{A}_{1,3}>\mu \mathrm{A}_{2,4}$
Dari hasil perhitungan dengan ANAVA tersebut didapat bahwa harga $\mathrm{F}_{\text {hitung }}$ sebesar 3,26 dan harga $F_{\text {Tabel }}=3,16$. Karena $\mathrm{F}_{\text {hitung }}>F_{\text {Tabel }}$ maka Ho ditolak dan hipotesis alternatif diterima. Dengan demikian hipotesis penelitian yang menyatakan hasil belajar TIK siswa yang memiliki motivasi berprestasi tinggi lebih tinggi dibandingkan dengan siswa yang memiliki motivasi berprestasi rendah, pada taraf kepercayaan $\alpha=0,05$ telah teruji kebenarannya.

Pengujian hipotesis ketiga: Terdapat interaksi antara media animasi dan motivasi berprestasi siswa dalam mempengaruhi hasil belajar TIK siswa kelas IX SMP Negeri 1 Pegajahan. Hipotesis statistiknya adalah:

$\mathrm{H}_{\mathrm{o}}$ : Interaksi $(\mathrm{B} \times \mathrm{T})=0$

$\mathrm{H}_{\mathrm{a}}$ : Interaksi $(\mathrm{B} \times \mathrm{T}) \neq 0$

Dari hasil perhitungan dengan ANAVA didapat bahwa harga $\mathrm{F}_{\text {hitung }}$ sebesar 3,77 dan harga $F_{\text {Tabel }}=3,16$. Karena $\mathrm{F}_{\text {hitung }}>F_{\text {Tabel }}$ maka Ho ditolak dan hipotesis alternatif diterima. Dengan demikian hipotesis penelitian yang menyatakan terdapat pengaruh interaksi antara media animasi dan motivasi berprestasi terhadap hasil belajar TIK pada taraf kepercayaan $\alpha=0,05$ telah teruji kebenarannya.

Data yang diperoleh dalam penelitian ini berasal dari dua sampel yang jumlahnya sama untuk tiap sel, sehingga perlu dilakukan uji Scheffe, ringkasan hasil pengujian dengan uji Scheffe dapat dilihat pada Tabel 2 berikut ini.

Tabel 3. Ringkasan Hasil dengan Menggunakan Uji Scheffe

\begin{tabular}{|c|c|c|c|c|}
\hline No & \multicolumn{2}{|c|}{ Hasil Uji Lanjut } & Fhitung & FTabel (0,05) \\
\hline 1 & $\mathrm{FA}_{1} \mathrm{~B}_{1}$ & $\mathrm{FA}_{2} \mathrm{~B}_{1}$ & 3,87 & 2,68 \\
\hline 2 & $\mathrm{FA}_{1} \mathrm{~B}_{1}$ & $\mathrm{FA}_{1} \mathrm{~B}_{2}$ & 14,74 & 2,68 \\
\hline 3 & $\mathrm{FA}_{1} \mathrm{~B}_{1}$ & $\mathrm{FA}_{2} \mathrm{~B}_{2}$ & 3,94 & 2,68 \\
\hline 4 & $\mathrm{FA}_{2} \mathrm{~B}_{1}$ & $\mathrm{FA}_{1} \mathrm{~B}_{2}$ & 3,62 & 2,68 \\
\hline 5 & $\mathrm{FA}_{2} \mathrm{~B}_{1}$ & $\mathrm{FA}_{2} \mathrm{~B}_{2}$ & 0,014 & 2,68 \\
\hline 6 & $\mathrm{FA}_{1} \mathrm{~B}_{2}$ & $\mathrm{FA}_{2} \mathrm{~B}_{2}$ & 2,92 & 2,68 \\
\hline
\end{tabular}


Dari hasil Uji Scheffe diperoleh kesimpulan, yaitu : (1) rata - rata hasil skor belajar TIK menggunakan media animasi 3D yang memiliki motivasi berprestasi tinggi lebih tinggi dari pada skor hasil belajar TIK menggunakan media animasi 2D yang memiliki motivasi berprestasi tinggi lebih tinggi, (2) rata - rata hasil skor TIK menggunakan media animasi 3D yang memiliki motivasi berprestasi tinggi lebih tinggi dari pada skor hasil belajar TIK menggunakan media animasi 3D yang memiliki motivasi berprestasi rendah, (3) rata rata hasil skor belajar TIK menggunakan media animasi 3D yang memiliki motivasi berprestasi tinggi lebih tinggi lebih dari pada skor hasil belajar TIK menggunakan media animasi 2D yang memiliki motivasi berprestasi rendah, (4) rata - rata hasil skor belajar TIK menggunakan media animasi 2D yang memiliki motivasi berprestasi tinggi lebih tinggi rendah dari pada skor hasil belajar TIK menggunakan media animasi 3D yang memiliki motivasi berprestasi rendah, (5) rata - rata hasil skor belajar TIK menggunakan media animasi 2D yang memiliki motivasi berprestasi rendah lebih tinggi dari pada skor hasil belajar TIK menggunakan media animasi 3D yang memiliki motivasi berprestasi tinggi, (6) rata - rata hasil skor belajar TIK menggunakan media animasi 3D yang memiliki motivasi berprestasi rendah lebih tinggi dari pada skor hasil belajar TIK menggunakan media animasi 2D yang memiliki motivasi berprestasi rendah. Interaksi antara media pembelajaran motivasi berprestasi dapat diilustrasikan dalam bentuk grafis pada Gambar 1 berikut ini:

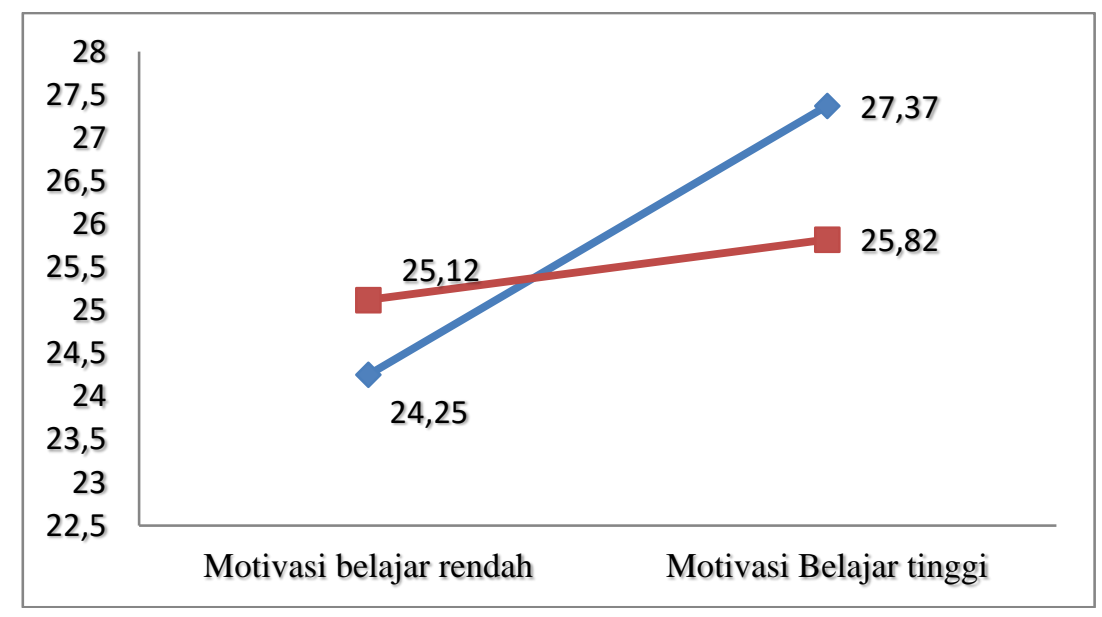

Gambar 1. Interaksi Media Animasi dan Motivasi Berprestasi Terhadap Hasil Belajar TIK

Berdasarkan hasil pengujian hipotesis ketiga yang menyatakan adanya interaksi antara media animasi dengan motivasi berprestasi, maka perlu dilakukan uji perbedaan rata - rata antara dua proposi. Gambar 4.9 menunjukkan pengaruh dan interaksi dari media animasi dan Pembahasan

Data yang diperoleh dalam penelitian ini ternyata membuktikan bahwa media animasi yang digunakan cukup signifikan untuk membedakan hasil belajar TIK sub jaringan komouter. Dari hasil analisis data diperoleh bahwa secara rata-rata hasil belajar TIK dengan menggunakan media animasi 3D lebih tinggi dari pada menggunakan media animasi 2D. Hal ini berindikasi bahwa media animasi 3D lebih baik dalam meningkatkan pemahaman siswa motivasi berprestasi terhadap hasil belajar TIK yang diperoleh siswa, rata - rata skor hasil belajar Tik yang diajar dengan menggunakan media animasi 3D lebih tinggi dibandingkan media animasi 2D

terhadap pembelajaran TIK. Dari hasil penelitian ini menunjukkan bahwa untuk mengajarkan materi pelajaran TIK lebih baik menggunakan media animasi 3D dibandingkan media animasi 2D.

Media animasi 3D merupakan media pempelajaran yang menggunakan perangkat computer dengan memproyeksikan karakter animasi yang diperlihatkan semakin hidup dan nyata, mendekati wujud manusia aslinya sehingga pembelajaran TIK menjadi lebih 
menarik dan tidak membosankan. Media animasi 3D dapat mendorong siswa untuk belajar secara aktif dan penuh semangat, serta siswa lebih mudah dan cepat menguasai pokok bahasan sesuai materi yang diajarkan. Selain itu dengan menggunakan media animasi 3D, siswa dapat melaksanakan tugas dan belajar secara bertahap dan mandiri, sehingga lebih mudah untuk menguasai materi yang diajarkan oleh guru dengan demikian hasil belajar siswa akan semakin tinggi.

Media animasi 3D ini menempatkan siswa pada posisi sentral dalam seluruh program pengajaran dan juga menumbuhkan keyakinan siswa dalam mengikuti mata pelajaran TIK. Media animasi 3D menekankan pembelajaran yang menyenangkan sesuai dengan karakteristik siswa dan secara psikologis memberikan dampak positif pada siswa dimana mereka lebih senang belajar mandiri dari pada hanya mendengarkan ceramah yang disampaikan guru.

Materi jaringan komputer dengan menggunakan media animasi 3D memberikan rangsangan kepada siswa dalam bentuk imajinasi, ide motivasi untuk lebih memahami materi pembelajaran. Hal ini karena dengan media animasi 3D siswa dapat melihat ilustrasi Gambar yang komrehensif dan menarik serta menghadirkan cara kerja nyata mengenai jaringan komputer di dalam kelas dibandingkan dengan media animasi 2D walaupun Gambar yang dihasilkan bergerak tetapi tidak terlihat nyata. Dengan tampilan nyata seperti hadirnya cara kerja jaringan komputer di dalam kelas, animasi 3D dapat mempengaruhi hasil belajar TIK dalam sub jaringan komputer dibandingkan dengan animasi 2D yang lebih terkesan Gambar biasa yang hanya bisa bergerak saja.

Hasil penelitian membuktikan bahwa motivasi berprestasi siswa cukup signifikan untuk membedakan hasil belajar TIK. Motivasi berprestasi siswa dalam penelitian ini dikategorikan atas dua kategori yaitu motivasi berprestasi tinggi dan motivasi berprestasi rendah. Dari hasil analisis data diperoleh bahwa secara rata-rata hasil belajar TIK siswa yang memiliki motivasi berprestasi tinggi lebih baik dari pada siswa yang memiliki motivasi berprestasi rendah. Hal ini berindikasi bahwa siswa yang mempunyai motivasi berprestasi tinggi secara rata-rata mempunyai hasil belajar TIK yang lebih baik dibandingkan siswa yang memiliki motivasi berprestasi yang rendah. Dengan demikian siswa yang mempunyai motivasi berprestasi yang tinggi lebih memahami pelajaran TIK dibandingkan siswa yang memiliki motivasi berprestasi rendah.

Motivasi berprestasi yang tinggi dapat meningkatkan pemahaman terhadap suatu masalah atau persoalan. Semakin tinggi motivasi berprestasi seseorang akan semakin kritis pemahamannya tentang suatu persoalan atau pemasalahan. Dengan demikian melalui pemahaman suatu persoalan dalam kegiatan belajar mengajar di kelas akan meningkatkan pemahaman tentang materi yang diberikan. Jadi siswa yang mempunyai motivasi berprestasi yang tinggi akan lebih baik memahami persoalan atau permasalahan TIK dalam kegiatan belajar sehingga hasil belajarnya lebih baik dibandingkan siswa yang mempunyai motivasi berprestasi yang rendah.

Dengan memiliki hasil belajar yang baik maka siswa dapat menyadari dalam kehidupan ini selalu mengalami perubahan, atau tidak mendapat apa yang diinginkan, timbul ketidakpuasan. Maka siswa memiliki motivasi berprestasi yang tinggi juga memiliki pemahaman yang baik tentang materi pelajaran sehingga siswa akan memiliki keyakinan terhadap penguasaan dan keterampilan dirinya.

Hasil penelitian diketahui bahwa terdapat interaksi antara media pembelajaran dan motivasi berprestasi siswa dalam mempengaruhi hasil belajar TIK siswa. Secara rata-rata kelompok siswa yang memiliki motivasi berprestasi tinggi dan diajar dengan menggunakan media animasi 3D mempunyai hasil belajar TIK yang lebih baik dibandingkan dengan menggunakan media animasi 2D. Kemudian secara rata-rata hasil belajar TIK kelompok siswa yang memiliki motivasi berprestasi rendah dan diajar dengan media pembelajaran animasi 3D lebih rendah dibandingkan dengan kelompok siswa yang memiliki motivasi berprestasi rendah tapi diajar dengan menggunakan media animasi 2D. Dengan kata lain bagi kelompok siswa yang memiliki motivasi berprestasi rendah lebih baik menggunakan media animasi 2D dibandingkan dengan menggunakan media animasi 3D, walaupun perbedaan hasil belajar TIK tersebut tidak signifikan. Jadi dalam hal ini media pembelajaran dan motivasi berprestasi siswa 
cukup signifikan untuk mempengaruhi hasil belajar TIK siswa.

Berdasarkan hasil belajar pendidikan TIK siswa secara keseluruhan, terjadi peningkatan hasil belajar sebelum perlakuan dan sesudah perlakuan, khususnya pada perlakuan media animasi 3D. Sedangkan pada kelas media animasi 2D, meskipun terjadi peningkatan hasil belajar, namun peningkatan rata-rata hasil belajar ini lebih baik dibandingkan dengan nilai rata-rata hasil belajaran yang selama ini dilaksanakan di lokasi penelitian.

\section{PENUTUP}

Berdasarkan hasil penelitian dan pembahasan yang telah dikemukakan sebelumnya, maka dapat disimpulkan

1. Hasil belajar TIK Sub Komputer Jaringan yang dibelajarkan dengan menggunakan media animasi 3Dlebih tinggi dibandingkan dengan hasil belajar TIK Sub Komputer Jaringan siswa yang dibelajarkan dengan menggunakan media animasi $2 \mathrm{D}$.

2. Hasil belajar TIK Sub Komputer Jaringansiswa yang memiliki motivasi berprestasi tinggi lebih tinggi daripada hasil belajar TIK Sub Komputer Jaringansiswa yang memiliki motivasi berprestasi rendah.

3. Terdapat interaksi antara media pembelajaran dengan motivasi berprestasi yang memberikan perbedaan pengaruh terhadap hasil belajar TIK Sub Komputer Jaringansiswa. Perbedaan pengaruh tersebut adalah:

a. Hasil belajar TIK Sub Komputer Jaringansiswa yang memiliki motivasi berprestasi tinggi yang dibelajarkan dengan menggunakan media animasi 3D lebih tinggi daripada hasil belajar TIK Sub Komputer Jaringansiswa yang memiliki motivasi berprestasi tinggi yang dibelajarkan dengan menggunakan media animasi 2D.

b. Hasil belajar TIK Sub Komputer Jaringansiswa yang memiliki motivasi berprestasi tinggi lebih tinggi dari pada hasil belajar TIK Sub Komputer Jaringan siswa yang memiliki motivasi berprestasi rendah yang dibelajarkan dengan media animasi 3D.

c. Hasil belajar TIK Sub Komputer Jaringansiswa yang memiliki motivasi berprestasi tinggi yang dibelajarkan dengan menggunakan media animasi 3D lebih tinggi dari pada hasil belajar TIK Sub Komputer Jaringansiswa yang memiliki motivasi berprestasi rendah yang dibelajarkan dengan media animas 2D.

d. Hasil belajar TIK Sub Komputer Jaringansiswa yang memiliki motivasi berprestasi tinggi yang dibelajarkan dengan media animasi 2D lebih tinggi dari pada hasil belajar TIK Sub Komputer Jaringan siswa yang memiliki motivasi berprestasi rendah yang dibelajarkan dengan media animasi 3D.

e. Hasil belajar TIK Sub Komputer Jaringansiswa yang memiliki motivasi berprestasi tinggi yang dibelajarkan dengan menggunakan media animasi 2D lebih tinggi dari pada hasil belajar TIK Sub Komputer Jaringansiswa yang memiliki motivasi berprestasi rendah yang dibelajarkan dengan menggunakan media animasi 2D.

f. Hasil belajar TIK Sub Komputer Jaringansiswa yang memiliki motivasi berprestasi rendah yang dibelajarkan dengan menggunakan media animasi 3D lebih rendah daripada hasil belajar TIK Sub Komputer Jaringan siswa yang memiliki motivasi berprestasi rendah yang dibelajarkan dengan menggunakan media animasi 2D.

\section{DAFTAR PUSTAKA}

Andreas, Andi S .2003. Menguasai Pembuatan Animasi dengan Flash MX. Jakarta :PTElex Media Komputindo.

Arikunto, Suharsimi. 2011 (Edisi Revisi). Prosedur Penelitian Suatu Pendekatan Praktik. Jakarta : Rineka Cipta.

$\begin{array}{rrr}\text { 2009. } & \text { Dasar-Dasar } & \text { Evaluasi } \\ \text { Pendidikan, } & \text { Jakarta } & \text { :Bumi }\end{array}$ Aksara.

Asnawir, M. Basyiruddin Usman. 2002.Media Pembelajaran. Jakarta: Ciputat Pers.

Dick, W. dan Carey, L. 2005. The Systematic Design of Instruction. United States 
of America: Scott Foresman and Company.

Chandra, Handi. 2012. 3ds Max 2012 untuk Orang Awam. Palembang : Maxikom.

Fahri, EmZuL \& Ratu Aprilia Senja. Edisi Revisi. Kamus Lengkap Bahasa Indonesia. Difa Publisher.

Hamalik, O. 2004. Perencanaan Pengajaran Berdasarkan Pendekatan Sistem. Jakarta: Bumi Aksara

Hamid K, Abdul. 2009. Teori Belajar dan Pembelajaran. Medan.

Hakim, Lukmanul. 2004. 111 RahasiadanTrikKreatif Flash MX. Jakarta : Elex Media Komputindo.

Hergenhahn, B.R dan Olson, M.H. 2008. Theories of Learning.Penerjemah : Tri Wibowo B.S. Jakarta : Kencana Prenada Media Group.

Sofana, Iwan. 2010. Cisco CCNA dan Jaringan Komputer. Bandung : Informatika.

Kusmulyadi, DyahSuci. 2009. Teknologi Informasi dan Komunikasi. Bandung :Thursina.

Lisnawati. 2009. Pengaruh Animasi 3D Terhadap Mata Pelajaran Kimia. Tesis. Bandung : UPI.

McClelland, David C. 1987. Memacu Masyarakat Berprestasi. Terjemahan Siswo Suyanto dan W.W. Bakowatun. Jakarta: CV. Intermedia.

McCleland, David C. 1976. The Projective Expresion of Needs. American Psychological Association.Inc

Romizowski, A.Z. 1981. Designing Instructional System.NewYork : Nichol Publishing Company.

Sadiman, A. dkk. 2003. Media Pendidikan, Pengertian, Pengembangan dan Pemanfaatannya . Jakarta : Pustekkom Dikbud.

Sardiman, A.M. 2006. Interaksi dan Motivasi Belajar Mengajar. Jakarta: Rajawali.

Snelbecker, E.G. 1974. Learning Theory, Instructional Theory and Psychoeducational Design, New York :McGraw Hill.

Sudjana dan Rivai. 2005. Media Pembelajaran. Bandung : Sianr Baru Algensindo.

Sudjana, Nana. 2004. Dasar-dasar Proses Belajar Mengajar. Bandung: Sinar Baru Algensindo.
Sudijono, Anas. 2009. Pengantar Statistik Pendidikan. Jakarta :Raja grafindo Persada.

Sujana. 2005. Metoda Statistika.Bandung :Tarsito.

Sugiyanto. 2007. "Kontribusi Gaya Belajar Dan Motivasi Berprestasi Terhadap Prestasi Akademik Siswa Kelas Xi Sma Negeri 10 Semarang”. Tesis. UNY:Yoyakarta.

Sukarno. 2009. Pengaruh Penggunaan Media Pembelajaran terhadap Prestasi Belajar PAI Siswa Kls XI IPA SMAN 3 Semarang. Semarang : IAIN Walisongo.

Surya, Hendra. 2009. Menjadi Manusia Pembelajar. Jakarta: Gramedia.

Syaiful, BahriDjamarahdanAsmanZein. 2006.StrategiBelajarMengajar.Jakarta: PT.RinekaCipta, 2006.

Syukur,

Fatah. 2005.TeknologiPendidikaSemarang: RaSAIL.

Tjutju Soendari, dkk. 2008. " Pengaruh Media Animasi Komputer Terhadap Hasil Belajar Sains Anak Tunagrahita Ringan (Studi eksperimen pada Ana k Kelas VI SDLB -C di SLB-C Sukapura)". Jurnal. UPI : Bandung.

Wahana Komputer. 2012. 3D Studio Max 2012. Yogyakarta : Penerbit Andi.

Wijaya, Kusumah. 2008. Media Pembelajaran ,(http://wijayalabs.blogspot.com). (diakses tanggal 10 September 2013)

Wina, Sanjaya. 2010. Perencanaan dan Desain Sistem Pembelajaran, Jakarta: Kencana Prenada Media Group

Woolfolk.A.E. (2009). Educational Psychology Active Learning Edition. Penerjemah : Helly Prajitno Soetjipto dan Sri Mulyanti Soetjipto. Psikologi Pendidikan. Yogyakarta :Pustaka Pelajar. 